\title{
Poselski projekt ustawy o powiecie metropolitalnym - progres czy regres $w$ reformowaniu samorządu terytorialnego w Polsce?
}

Streszczenie: Rozwój samorządu terytorialnego jest jednym z kluczowych czynników, które przyczyniły się do demokratyzacji systemu politycznego w Polsce. Proces budowy samorządu terytorialnego w Polsce nie jest skończony, a przed nami pojawiają się nowe wyzwania. Jednym z istotnych zagadnień jest kwestia zwiększenia roli metropolii i dużych aglomeracji miejskich. Przedmiotem artykułu stała się analiza poselskiego projektu ustawy o powiecie metropolitalnym. Przedstawiony projekt nie przystaje do samorządowej rzeczywistości. Nie ulega jednak wątpliwości, że dobrze się stało, iż ten projekt trafił pod obrady parlamentu, bowiem stał się podstawą do ożywionej dyskusji. W jej efekcie wypracowano nowe rozwiązanie - ustawę o związkach metropolitalnych.

Slowa kluczowe: obszar metropolitalny, powiat metropolitalny, samorząd terytorialny

\section{Wstęp}

Wtym roku obchodzimy 26 rocznicę restytucji samorządu terytorialnego w Polsce. Tego typu jubileusz zawsze skłania do refleksji na temat tego co udało się osiagnąć, gdzie zawiedliśmy i co jeszcze przed nami. Nie ulega bowiem wątpliwości, że rozwój samorządu terytorialnego jest jednym z kluczowych czynników, które przyczyniły się do demokratyzacji systemu politycznego w Polsce. Odwołanie się do idei samorządności należy uznać za jeden z fundamentów ustrojowych III Rzeczypospolitej (Antkowiak, 2015, s. 161-165).

Rok 1989 przyniósł wiele zmian ustrojowych, w tym m.in. restytucję samorządu terytorialnego. Reformy wprowadzone pakietem ustaw z 1990 roku przywróciły zjawisko władzy lokalnej w Polsce. W dniu 8 marca 1990 roku Sejm uchwalił nowelizację Konstytucji, stwierdzając w art. 5, że „Rzeczpospolita Polska gwarantuje udział samorządu terytorialnego w sprawowaniu władzy" oraz uzupełniając ją nowym rozdziałem poświę- 
conym samorządowi. W tym samym dniu uchwalono jeszcze dwie ustawy o fundamentalnym znaczeniu dla funkcjonowania polskiego samorzą$\mathrm{du}$ - ustawę o samorządzie terytorialnym (obecnie gminnym) i ordynację wyborczą do rad gmin. Uwieńczeniem wysiłku reformatorów tamtego okresu było przeprowadzenie wyborów samorządowych w dniu 27 maja 1990 roku. Wtedy właśnie odbyły się w pełni wolne i demokratyczne wybory do rad gmin i jednocześnie realnie zapoczątkowany został proces budowy nowego modelu państwa (Antkowiak, 2011a, s. 155-174).

Pod auspicjami nowej Konstytucji z 1997 roku rozpoczął się drugi etap reformy samorządowej, który miał na celu wprowadzenie dwóch wyższych szczebli jednostek samorządu terytorialnego, a mianowicie powiatu oraz województwa. W dniu 5 czerwca 1998 roku przyjęto ustawy o samorządzie powiatowym, o samorządzie województwa oraz o administracji rządowej w województwie. Na mocy tych aktów prawnych z dniem 1 stycznia 1999 roku powstał trójstopniowy podział terytorialny: gminy (2479), powiaty (379, w tym 314 powiatów ziemskich oraz 65 miast na prawach powiatu) oraz województwa (16) (Antkowiak, 2011b, s. 34-43).

Według zamierzeń twórców reform samorządowych, podstawowymi celami ich wprowadzenia miała być decentralizacja państwa poprzez przeniesienie wielu zadań i kompetencji z centrum do jednostek samorządowych, a także budowa instytucji demokracji obywatelskiej. Założenie było bardzo proste - im bliżej obywatela zapadać będą decyzje, tym trafniej odpowiadać one będą na społeczne zapotrzebowanie. I tak de facto jest, chociaż przyznać trzeba, że nie wszystko się udało. Ciagle dyskutujemy nad zasadami finansowania działalności samorządów, zakresem ich kompetencji, przekazywaniem kolejnych zadań samorządom bez zabezpieczenia odpowiednich środków finansowych etc. Na wielką pochwałę zasługuje sposób wydatkowania pieniędzy unijnych przez polskie samorządy.

Warto jednak pamiętać, że proces budowy samorządu terytorialnego w Polsce nie jest skończony, a przed nami pojawiają się nowe wyzwania. Wydaje się, że należy coraz intensywniej włączać inne - zewnętrzne podmioty w proces sprawowania władzy na poziomie lokalnym. Chodzi przede wszystkim o włączenie organizacji pozarządowych, przedstawicieli świata biznesu oraz mieszkańców w proces podejmowania decyzji publicznych. Coraz większą popularność zdobywają też tzw. budżety obywatelskie, powstają rady osiedli czy rady dzielnic, konsultacje społeczne nabierają nowego znaczenia i charakteryzują się wyższą jakością 
aniżeli na początku lat 90 . Nie ulega bowiem wątpliwości, że samorząd stał się znakomitą szkołą wyrobienia obywatelskiego i przyczynia się do budowy społeczeństwa obywatelskiego.

Jednym $\mathrm{z}$ istotnych zagadnień poruszanych w ostatnich latach w dyskursie naukowym jest kwestia zwiększenia roli metropolii i dużych aglomeracji miejskich. Przedmiotem artykułu stała się analiza poselskiego projektu ustawy o powiecie metropolitalnym (druk nr 2107). Artykuł powstał na bazie przygotowanej wcześniej opinii autora zleconej przez Komisję Samorządu Terytorialnego i Polityki Regionalnej za pośrednictwem Biura Analiz Sejmowych (Antkowiak, 2014, s. 1-14). Opinia ta stała się podstawą do krytycznej dyskusji w trakcie trwania prac sejmowych i do istotnej modyfikacji projektu, który ostatecznie został przyjęty przez Parlament RP i podpisany przez Prezydenta RP w zgoła odmiennej postaci. Jak się wydaje, wiele zaleceń zawartych w przedmiotowej opinii znalazło odzwierciedlenie w ostatecznej wersji ustawy z dnia 9 października 2015 roku o zwiazkach metropolitalnych (Ustawa z dnia 9 października 2015 roku...).

\section{Proces metropolizacji}

Nie ulega wątpliwości, że proces metropolizacji stanowi jeden z najważniejszych czynników rozwojowych współczesnych państw demokratycznych. Zmiana metod zarządzania obszarami metropolitalnymi stała się wreszcie przedmiotem zainteresowania ustawodawcy i doprowadziła do przyjęcia nowych przepisów prawnych, które umożliwią skuteczniejsze ich działanie (Nawrot, 2011, s. 169). Dotychczas funkcjonujące rozwiązania prawne nie stanowiły kompleksowej odpowiedzi na problem, jakim jest wzrastająca rola obszarów metropolitalnych, która stanowi efekt koncentracji przestrzennej gospodarki w dużych miastach i ich otoczeniu oraz towarzyszące temu zjawisko suburbanizacji. Dalsze trwanie w swoistego rodzaju ,niemocy” rzutowałoby na jakość współpracy jednostek samorządu terytorialnego wchodzących w skład obszarów metropolitalnych (Kaczmarek, 2008, s. 15).

Warto przypomnieć, że rola i znaczenie ośrodków wielkomiejskich od początku reform samorządowych była szczególna, ale niedostrzeżona w początkowej fazie reform. Rację ma Beata Słobodzian, gdy pisze, że na mocy ustawy o samorządzie terytorialnym z 1990 roku wielkie miasta miały taki sam status jak małe gminy, co powodowało ich dysfunkcjo- 
nalność oraz brak możliwości dalszego rozwoju. Skala zadań stojących przed dużym miastem jest diametralnie różna aniżeli małej gminy wiejskiej (Słobodzian, 2011, s. 161).

Od 1993 roku rozpoczęto prace nad „Miejskim programem pilotażowym”, którego zadaniem było m.in. „zintegrowanie rozproszonych dotąd zadań, kompetencji, finansów na terenie największych miast polskich, ustalenie jasnego podziału kompetencji i odpowiedzialności między administracją rządową i samorządową" (Wierzba, 2006, s. 26). Równolegle do prowadzonych prac nad reorganizacją terytorialną państwa przygotowano drugi wariant powiatowej reformy, czyli tzw. pilotażowy program miejski (Program Pilotażowy...).

Tymczasem kolejne nowelizacje prawa samorządowego prowadziły do przejmowania coraz to nowych zadań i kompetencji przez duże miasta. W roku 1995 pojawiła się ustawa o zmianie zakresu działania niektórych miast oraz miejskich strefach usług publicznych, zwanej potocznie ustawą o dużych miastach bądź ustawą miejską (Ustawa z dnia 24 listopada 1995 roku...). Na jej mocy gminy uzyskały kolejne kompetencje i przejmowały coraz to większą odpowiedzialność za realizację zadań publicznych.

Miejskie strefy publiczne przestały funkcjonować z dniem 31 grudnia 1998 roku. Od 1 stycznia roku następnego swoje funkcjonowanie rozpoczęły powiaty, w tym ważne dla naszych rozważań miasta na prawach powiatu. Upłynęły dwa lata zanim ustawodawca jasno dał do zrozumienia, że miasto na prawach powiatu jest gmina, która wykonuje zadania powiatu na zasadach określonych w ustawie o samorządzie powiatowym. Widać również wyraźnie, że miasta różnie radziły sobie z przyjęciem na siebie nowych obowiązków. Wydaje się, że w nieco lepszej sytuacji znalazły się te, które uczestniczyły w programie pilotażowym oraz działały w oparciu o wspomnianą ustawę z 1995 roku (Słobodzian, 2011, s. 162-163).

Od lat podkreślano więc, że jednym z elementów wieńczących reformy samorządowe w Polsce powinno być przyjęcie rozwiązań prawnych, które pozwoliłyby wykorzystać szansę na skok cywilizacyjny w oparciu o wysoką motorykę rozwojową dużych ośrodków miejskich. Warto więc odkreślić, że w Polsce podejmowano wcześniej próby unormowania tego zagadnienia. Najważniejsze projekty ustaw dotyczące tej materii to:

- ustawa o rozwoju miast, centrach rozwoju regionalnego i obszarach metropolitalnych (Projekt ustawy o rozwoju...);

- ustawa o polityce miejskiej i współpracy jednostek samorządu terytorialnego w tym zakresie oraz zmianach niektórych innych ustaw (Projekt ustawy o polityce...); 
- ustawa o ustroju obszarów metropolitalnych (Projekt ustawy o ustroju...);

- ustawa o obszarach metropolitalnych (Projekt ustawy o obszarach...).

Brak jednolitych założeń i zgody co do modelowych rozwiązań sprawiał, że przez lata nie udało się wdrożyć żadnej z tych koncepcji.

Warto też podkreślić, że problematyka związana z rozwojem obszarów metropolitalnych została wyraźnie dostrzeżona w nowych polskich dokumentach strategicznych. Wskazać tu należy m.in. Dlugookresowa Strategię Rozwoju Kraju Polska 2030. Trzecia fala nowoczesności (Dtugookresowa...). Postuluje się tam intensywny rozwój sieci metropolitalnej sprowadzający się do przygotowania nowych rozwiązań prawnych i organizacyjnych. Kwestia metropolitalna pojawia się również w Koncepcji Przestrzennego Zagospodarowania Kraju 2030 (Koncepcja...) oraz w Krajowej Strategii Rozwoju Regionalnego 2010-2020: Regiony, miasta, obszary wiejskie (Krajowa Strategia...). Oba dokumenty strategiczne podkreślają znaczenie największych ośrodków miejskich dla rozwoju kraju. Ministerstwo Infrastruktury i Rozwoju pracuje także nad Krajowa Polityka Miejska (Krajowa Polityka...), której celem ma być poprawa efektywności interwencji publicznej, koordynacji polityk sektorowych na obszarach miejskich oraz rozwiązanie kluczowych problemów miast, dla realizacji celów rozwojowych kraju.

Równolegle w Ministerstwie Administracji i Cyfryzacji trwały prace, które objawiły się najpierw w postaci Zielonej Księgi dotyczqcej Obszarów Metropolitalnych z 2012 roku (Zielona Księga..., 2012), a potem w postaci Białej Księgi Obszarów Metropolitalnych z 2013 roku (Biata Księga..., 2013). W dokumentach tych zwrócono uwagę na podstawowe mankamenty dotychczasowych rozwiązań i postulaty wysuwane przez środowisko samorządowe. Warto wskazać konkluzję, jaka wypływa z ustaleń ministerstwa w odniesieniu do obszarów metropolitalnych. Otóż sposobem na wzmocnienie metropolii miała być oddolna integracja zarządzania wsparta zachętami finansowymi. Miał to być początek wypracowywania rozwiązań, których dynamika oraz kierunek będą zależały od władz samorządowych znajdujących się w ramach obszarów metropolitalnych. Zdaniem autorów opracowania narzucanie rozwiązania dla całego kraju w drodze odgórnej reformy nie byłoby skutecznym rozwiązaniem, gdyż opierałoby się na uogólnieniach, które mogłyby nie odzwierciedlać realnych potrzeb polskich miast. Należy też dodać, że Rada Ministrów przyjęła założenia do projektu ustawy o poprawie funk- 
cjonowania i organizacji wykonywania zadań publicznych przez jednostki samorządu terytorialnego, które zostały przygotowane w Ministerstwie Administracji i Cyfryzacji.

Niejako w kontrze do przedstawionych wyżej dokumentów i projektów, w szczególności tych przygotowanych i wdrażanych przez Ministerstwo Infrastruktury i Rozwoju oraz Ministerstwo Administracji i Cyfryzacji, w 2013 roku do Sejmu wpłynął poselski projekt ustawy o powiecie metropolitalnym. Od początku wzbudzał on poważne wątpliwości i stał się przedmiotem ożywionej dyskusji ${ }^{1}$. Przede wszystkim jednak znacząco

${ }^{1}$ Opinia prawna w sprawie zgodności z prawem Unii Europejskiej poselskiego projektu ustawy o powiecie metropolitalnym, Biuro Analiz Sejmowych Kancelarii Sejmu; Opinia Prokuratora Generalnego o projekcie ustawy o powiecie metropolitalnym; Opinia Polskiej Izby Inżynierów Budownictwa o projekcie ustawy o powiecie metropolitalnym; Opinia Krajowej Izby Urbanistów o projekcie ustawy o powiecie metropolitalnym; Uwagi Województwa Małopolskiego do projektu ustawy o powiecie metropolitalnym; Uwagi woj. łódzkiego dotyczące poselskiego projektu ustawy o powiecie metropolitalnym, Departament Polityki Regionalnej; Opinia o projekcie ustawy o powiecie metropolitalnym, Urząd Marszałkowski Województwa Śląskiego; Uwagi woj. opolskiego do projektu ustawy o powiecie metropolitalnym; Opinia województwa zachodniopomorskiego w sprawie poselskiego projektu ustawy - o powiecie metropolitalnym; Województwo pomorskie - uwagi do poselskiego projektu ustawy o powiecie metropolitalnym - wniesionym do Marszałka Sejmu przez grupę posłów Platformy Obywatelskiej, skierowanym do opinii organizacji samorządowych; Opinia o projekcie ustawy o powiecie metropolitalnym, Urząd Marszałkowski Województwa Mazowieckiego w Warszawie; Opinia o projekcie ustawy o powiecie metropolitalnym województwa kujawsko-pomorskiego; Uwagi do projektu ustawy o powiecie metropolitalnym, Urząd Marszałkowski Województwa Warmińsko-Mazurskiego w Olsztynie; Opinia o projekcie ustawy o powiatach metropolitalnych, Związek Powiatów Polskich; Stanowisko Konwentu Marszałków Województw RP nr 43/2013/K-P z dnia 5 grudnia 2013 roku w sprawie projektu ustawy o powiecie metropolitalnym; Stanowisko Krajowej Rady Architektów RP w sprawie projektu ustawy o powiecie metropolitalnym; Stanowisko Zarządów Związku Miast Polskich i Śląskiego Związku Gmin i Powiatów w sprawie poselskiego projektu ustawy o powiecie metropolitalnym; Opinia Strony Samorządowej Zespołu ds. Ustrojowych Komisji Wspólnej Rządu i Samorządu Terytorialnego w sprawie projektu stawy o związkach metropolitalnych; Wspólne stanowisko regionalnych organizacji samorządowych przyjęte na spotkaniu Ogólnopolskiego Porozumienia Organizacji Samorządowych w Nowej Soli w dniu 29 października 2013 roku na temat projektu ustawy o powiecie metropolitalnym oraz projektu ustawy o współdziałaniu w samorządzie terytorialnym na rzecz rozwoju lokalnego i regionalnego oraz zmianie niektórych ustaw; Stanowisko Rady Ministrów wobec poselskiego projektu ustawy o powiecie metropolitalnym (druk 2107); Stanowisko Zgromadzenia Ogólnego Śląskiego Związku Gmin i Powiatów w sprawie poselskiego projektu ustawy o powiecie metropolitalnym, dn. 25 października 2013 roku. 
odbiegał on od realizowanych już projektów modernizacji polskiego samorządu terytorialnego w zakresie polityki wielkomiejskiej. Warto więc przyjrzeć się tej propozycji z należytą starannością.

\section{Przepisy ogólne projektu}

Rozważania należy zacząć od tego, że z projektu ustawy jednoznacznie wynika, iż tworzona jest nowa jednostka samorządu terytorialnego. Oznacza to, że w dotychczasowym trójstopniowym zasadniczym podziale terytorialnym państwa pojawia się dodatkowy element. Świadczą o tym art. 1-7 (Poselski...), ale także, o czym mowa będzie później, charakter realizowanych zadań, sposób finansowania, kwestie przejęcia majątku, procedury wyborcze względem organów powiatu metropolitalnego i inne. Charakter tej jednostki (Poselski..., art. 1) nie wypełnia bowiem znamion powiatu ani regionu, ma być czymś pośrednim. Bezwarunkowo należy odrzucić wyjaśnienia projektodawcy, który w uzasadnieniu do projektu stara się lokować powiat metropolitalny na poziomie drugim - czyli powiatowym. Wyraźnie przesądza o tym katalog zadań stawianych przed nowo powoływaną jednostką terytorialną, który w żadnym razie nie stanowi substytutu wyzwań stawianych przed funkcjonującymi obecnie: powiatem ziemskim i miastem na prawach powiatu (grodzkim). Ponadto, co istotne, projekt ustawy nie znosi ,tradycyjnego powiatu” na terenie objętym powiatem metropolitalnym. Można odnieść wrażenie, że w trójstopniowej skali powiat metropolitalny należy ulokować na poziomie ,2,5”, co już w założeniu jest zabiegiem niezasadnym. Warto również podkreślić, że wbrew zapisom projektu (Poselski..., art. 3 ust. 1) zakres działania powiatu metropolitalnego $\mathrm{w}$ istotny sposób narusza samodzielność powiatu, miast na prawach powiatu, gminy, ale także województwa, o czym będzie mowa później.

Uzasadnione wątpliwości budzi również sposób tworzenia powiatu metropolitalnego w drodze rozporządzania Rady Ministrów (Poselski..., art. 4), która wprawdzie może zasięgnąć opinii mieszkańców danej wspólnoty, ale konsultacje te nie są w żaden sposób wiążące. Z jednej strony projektodawca stwierdza, że inicjatorem utworzenia powiatu metropolitalnego może być zainteresowana rada powiatu, rada miasta na prawach powiatu lub rada gminy (Poselski..., art. 4, ust. 2). Z drugiej strony, gdy pisze o kwestii opiniowania pomysłu na utworzenie nowego powiatu metropolitalnego, zamierza konsultować to obowiązkowo 
z radami powiatów i miast na prawach powiatu (które zobowiązuje do prowadzenia konsultacji z mieszkańcami), względnie z sejmikami województw (gdy powiat miałby naruszać ich granice), ale w stosunku do rad gmin wprowadza fakultatywne konsultacje z radą gminy, podkreślając jednocześnie brak wymogu zasięgnięcia opinii mieszkańców (Poselski..., art. 5, ust. 1). Podsumowując wynika z tego jednoznacznie, że gminy mogą przymusowo zostać członkiem wspólnoty samorządowej, co stoi w wyraźnej sprzeczności z procesami koncentracji poszczególnych podmiotów wokół metropolii.

W ustawie założono także, że granice obszaru metropolitalnego obejmować będą tereny poszczególnych gmin czy powiatów. Tym samym odrzucono koncepcję, aby ich obszar mógł przecinać teren powiatu oraz wykraczać poza teren województwa, jeśli tylko znajduje to logiczne i funkcjonalne uzasadnienie. Trzeba również odnotować, że ustawa nie precyzuje żadnych kryteriów, jakie muszą być spełnione by utworzyć powiat metropolitalny. Pozostawione jest to arbitralnej decyzji Rady Ministrów. Czy to oznacza, że można będzie tworzyć powiat metropolitalny wokół miasta 40-tysięcznego, jeśli takie ambicje będą mieć lokalne władze samorządowe?

Ponadto w zasadzie w całym projekcie można odnieść wrażenie, że projektodawca zapomniał o gminie, jako podstawowej jednostce samorządu terytorialnego, skupiając swoją uwagę na miastach na prawach powiatu. Jest to widoczne m.in. w części dotyczącej finansów powiatu metropolitalnego, o czym będzie mowa dalej. Nie ulega wątpliwości, co podkreśla zresztą sam projektodawca w uzasadnieniu, że bazą dla przygotowania projektu była Aglomeracja Górnośląska, która charakteryzuje się specyficzną struktura, bowiem składa się z 14 miast na prawach powiatu (odgrywających kluczową rolę) oraz otaczających je powiatów ziemskich. Tymczasem w Polsce w większości przypadków koncentracja kapitału społeczno-gospodarczego ogniskuje się wokół jednego dużego ośrodka miejskiego, który kooperuje z otaczającymi je gminami czy całymi powiatami. Wydaje się, że przygotowany projekt nie przystaje do warunków funkcjonowania ośrodków wielkomiejskich w Polsce.

\section{Zakres działania i zadania powiatu metropolitalnego}

Zakres działania i katalog zadań realizowanych przez powiat metropolitalny (Poselski..., art. 8) jest niespójny i nieadekwatny do realiów 
funkcjonowania obszarów metropolitalnych w Polsce. Wynika z niego, że wiele proponowanych zadań nakłada się na te, które realizują inne jednostki samorządu terytorialnego. Istnieje więc poważne ryzyko, że zaistniała sytuacja wygeneruje niepotrzebne spory kompetencyjne i niewątpliwie skomplikuje proces decyzyjny w dotychczas funkcjonujących jednostkach. Należy również wyraźnie powiedzieć, że coś, co projektodawca nazywa w uzasadnieniu przeniesieniem na szczebel metropolitalny zadań ponadlokalnych, kluczowych dla rozwoju całej aglomeracji, jest de facto ograniczeniem dotychczasowych kompetencji gmin, miast na prawach powiatu, ale także województw, a co za tym idzie ograniczeniem dopływu środków finansowych dla tych jednostek. Warto zwrócić uwagę na kilka elementów. Otóż powiat metropolitalny miałby przyjać i realizować wspólną strategię rozwoju (Poselski..., art. 8, ust. 1, pkt 1). W projekcie nie przewidziano natomiast żadnych mechanizmów, które zapewniłyby spójność tej strategii z analogicznymi dokumentami na poziomie gminy i „tradycyjnego" powiatu. Na czym więc miałaby polegać rzeczona „wspólnotowość” proponowanego dokumentu strategicznego?

Powiat miałby również uchwalać studium uwarunkowań i kierunków zagospodarowania przestrzennego powiatu metropolitalnego, które na dodatek miałoby stanowić wiążące wytyczne dla miast będących członkami powiatu metropolitalnego w procesie tworzenia gminnych studiów uwarunkowań i kierunków zagospodarowania przestrzennego oraz gminnych planów zagospodarowania przestrzennego (Poselski..., art. 8, ust. 1, pkt 2). Zapis ten w wyraźny sposób ingeruje w samodzielność gmin w zakresie planowania przestrzennego. Czy studium metropolitalne miałoby być sumą studiów gminnych? Tego projekt nie precyzuje. Ponadto projektodawca pisząc o wiążących wytycznych względem miast, kontynuując swój wywód, rozszerza tę kategorię o gminy. Kogo więc dotyczyć będą te wytyczne? Ten fragment został zredagowany bardzo nieprecyzyjnie. Warto też odnotować fakt, że pisząc $\mathrm{w}$ dalszej części projektu (Poselski..., art. 34, ust. 2, pkt 1) o zadaniach stawianych przed zarządem powiatu metropolitalnego użyto sformułowania ,przygotowanie [...] projektu planu zagospodarowania przestrzennego powiatu metropolitalnego". Trzeba więc wyraźnie podkreślić, że rzeczone „studium” oraz „plan” to dwa różniące się od siebie dokumenty. Efekt projektu jest taki, że powiat ma przygotować jeden z nich, a jego organ wykonawczy drugi. Jest to poważny błąd, który wymagałby ujednolicenia - albo powiat przygotowuje jeden $\mathrm{z}$ tych dokumentów, albo oba - w obydwu przypadkach wymaga to zmiany przepisów projektu. 
Powiat miałby organizować i wykonywać publiczny transport zbiorowy na jego obszarze (Poselski..., art. 8, ust. 1, pkt 3). Zapis ten nie precyzuje jednak o jaki transport chodzi, ale można domniemywać, że projektodawca miał na myśli transport zintegrowany. Przed powiatem postawiono również zadanie planowania sieci i zarządzania drogami publicznymi krajowymi i wojewódzkimi na obszarze powiatu metropolitalnego (Poselski..., art. 8, ust. 1, pkt 4). Należałoby sprecyzować, czy w zakresie dróg krajowych mieszczą się również autostrady i drogi ekspresowe? Pomijając to pytanie z przepisu tego wynika jednoznacznie, że projekt odbiera kompetencje miastom na prawach powiatu, samorządowi województwa, a nawet Generalnej Dyrekcji Dróg Krajowych i Autostrad.

Powiat miałby uchwalać i realizować programy ochrony środowiska, gospodarki wodno-ściekowej oraz gospodarki odpadami na swoim obszarze (Poselski..., art. 8, ust. 1, pkt 5). Nie ulega wątpliwości, że wymagałoby to ingerencji $\mathrm{w}$ ustawach normujących te zagadnienia, które wymieniono w dalszej części tego opracowania. W ręce powiatu metropolitalnego przekazano również uchwalanie planu zaopatrzenia w ciepło, energię elektryczną i paliwa gazowe dla powiatu metropolitalnego (Poselski..., art. 8, ust. 1, pkt 6). Wygląda więc na to, że odbieramy te kompetencje gminom.

Powiat metropolitalny miałby również uchwalać programy metropolitalne w zakresie bezpieczeństwa publicznego i zarządzania kryzysowego (Poselski..., art. 8, ust. 1, pkt 7). Warto dodać, że w art. 10 ust. 1 (Poselski...) stwierdzono także, że organy administracji rządowej mogą nałożyć na powiat metropolitalny obowiązek wykonania określonych czynności w zakresie należącym do zadań powiatu, związanych z usuwaniem bezpośrednich zagrożeń dla bezpieczeństwa i porządku publicznego oraz $\mathrm{z}$ obronnością. Projekt nie odnosi się natomiast w żadnym stopniu do przepisów ustawy z dnia 26 kwietnia 2007 roku o zarzqdzaniu kryzysowym (Dz. U. 2013, poz. 1166), która w sposób kompleksowy reguluje wspomniane wyżej kwestie.

\section{Wladze powiatu metropolitalnego}

Ustrój powiatu metropolitalnego jest zasadniczo powieleniem ustroju powiatu. Organami będą rada powiatu metropolitalnego - jako organ stanowiący i kontrolny oraz zarząd powiatu metropolitalnego - jako organ wykonawczy (Poselski..., art. 12-13). Wątpliwości budzi bezpośredni 
wybór 15-osobowej rady powiatu metropolitalnego. Zdaniem projektodawcy miałoby to pozwolić na ,uniknięcie konfliktów kompetencyjnych pomiędzy organami” oraz ,przełamać partykularyzm lokalny radnych”. Metodą na owo „przełamanie" miałoby być m.in. takie skonstruowanie okręgów wyborczych, aby przekraczały one granice miast. W przekonaniu autora taki sposób elekcji byłby bardzo trudny do wprowadzenia tam, gdzie do tej pory funkcjonowały rady (np. w stowarzyszeniach funkcjonujących wokół dużych ośrodków miejskich jak Poznań), złożone z osób delegowanych z poszczególnych jednostek samorządu wchodzących w skład metropolii. Należy bowiem zadać sobie zasadnicze pytanie: Jaka w tym modelu miałaby być rola prezydentów miast na prawach powiatu, włodarzy gmin czy starostów powiatów ziemskich? W ocenie autora, projekt pomija zupełnie rolę tych osób w zarządzaniu powiatem metropolitalnym. Tymczasem w polskiej rzeczywistości samoorganizacja ośrodków metropolitalnych opiera się właśnie na kooperacji funkcjonujących już jednostek samorządu terytorialnego. Dodać należy, że odbywa się ona w trudnych warunkach, bowiem do dziś, mimo usilnych starań środowisk naukowych i samorządowych, nie udało się wprowadzić chociażby możliwości nawiązania współpracy na zasadach związku między gminą i powiatem. Wydaje się, że proponowane rozwiązanie nie przystaje do polskiej rzeczywistości i może wywołać destabilizujące spory polityczne, które doprowadzą do dezintegracji kooperujących środowisk samorządowych.

Warto też odnotować, że same zasady wyboru rady powiatu metropolitalnego potwierdzają tezę, iż mamy do czynienia z nową jednostką samorządową (Poselski..., art. 14, ust. 3). Wybory mają być bowiem przeprowadzone w oparciu o przepisy ustawy z dnia 5 stycznia 2011 roku Kodeks wyborczy (Dz. U. 2011, Nr 21, poz. 112) dotyczące wyboru radnych do sejmików województw, natomiast podział na okręi wyborcze ma być dokonany w oparciu o przepisy dotyczące wyborów do rad powiatów.

Novum jest niewątpliwie to, że przewodniczącym zarządu powiatu metropolitalnego oraz przewodniczącym rady powiatu metropolitalnego będzie jedna i ta sama osoba, a mianowicie ,starosta metropolitalny” (Poselski..., art. 18, ust. 1 oraz art. 28, ust. 2). Czy takie połączenie ma rację bytu? W ocenie autora nastręcza ono wielu praktycznych trudności. O dwóch należy koniecznie wspomnieć. Po pierwsze stoi ono w wyraźnej sprzeczności z zasadą rozdziału organu wykonawczego i stanowiącokontrolnego. Nie można bowiem zapominać, że rada pełni wobec starosty funkcję kontrolną. Jak zatem zwoływane i prowadzone będzie posiedzenie rady, w sytuacji gdy jej przedmiotem będzie np. wniosek o nieudzie- 
lenie absolutorium? Wprawdzie projektodawca przewiduje, że starosta nie bierze udziału w głosowaniu, gdy sprawa dotyczy jego interesu prawnego (Poselski..., art. 18, ust. 3), ale nadal zwołuje posiedzenie oraz przewodniczy jego obradom. Jest to sytuacja bardzo niezręczna, wręcz konfliktowa $\mathrm{i}$ do tej pory nieznana w analogicznych przepisach ustawy o samorządzie powiatowym oraz wojewódzkim. Po drugie, nie bardzo wiadomo, kto miałby w proponowanym rozwiązaniu wykonywać czynności z zakresu prawa pracy związane z nawiązaniem i rozwiązaniem stosunku pracy ze starostą metropolitalnym, o czym mowa w ustawie z dnia 21 listopada 2008 roku o pracownikach samorzqdowych (Dz. U. 2008, $\mathrm{Nr} 223$, poz. 1458 z późn. zm.). W dotychczasowych rozwiązaniach funkcję tę wobec starosty pełnił przewodniczący rady powiatu, z tym, że wynagrodzenie ustalała rada powiatu. Zachowanie tej propozycji wymagałoby zmian w rzeczonej ustawie.

\section{Mienie i finanse powiatu metropolitalnego}

Ta część ustawy zawiera w sobie bardzo niebezpieczny element, który nazwany wprost polegać ma na swoistego rodzaju ,wywłaszczeniu” gmin. Powiat metropolitalny miałby bowiem nabyć mienie m.in. w drodze przekazania składników majątkowych przez gminy wchodzące w jego skład (Poselski..., art. 44, ust. 1, pkt 1). Przekazanie zakłada dobrowolność, tymczasem w projekcie stwierdza się, że to Rada Ministrów w drodze rozporządzania określi wykaz składników majątkowych i tryb ich przekazania powiatowi przez gminy z jego terenu (Poselski..., art. 44, ust. 2, pkt 1). Tego rodzaju rozwiązanie wygeneruje niepotrzebne spory i obawy wśród włodarzy gmin, że powstający powiat w pierwszej kolejności będzie miał przejąć dobrze rozwinięte elementy infrastruktury gminnej, pozbawiając ją tym samym szans rozwojowych. Należy też wskazać, że projektodawca mija się z prawdą stwierdzając, że proponowane rozwiązanie jest analogiczne do zastosowanego w 1999 roku w przypadku powiatów ziemskich i grodzkich. Trzeba bowiem wyraźnie podkreślić, że w owym czasie nie przekazywano powiatom składników mienia innych jednostek samorządowych, a już na pewno nie w formie arbitralnej decyzji Rady Ministrów, co proponuje projektodawca.

Najwięcej wątpliwość budzi art. 68 (Poselski...), który bardzo ogólnikowo określa sposób finansowania powiatu metropolitalnego, co nie daje podstaw do precyzyjnego orzeczenia o ewentualnych kosztach tej pro- 
pozycji. Razi przede wszystkim fakt, że powiat miałby pozyskać środki finansowe w zasadzie tylko kosztem miast, a nie wszystkich podmiotów wchodzących w jego skład (np. gmin). Zapis jest również o tyle kłopotliwy, że stwierdzając o przeniesieniu środków z istniejących jednostek samorządowych, nie przewiduje przejęcia ich konkretnych zobowiązań przez powiat metropolitalny. Nie ulega wątpliwości, że tego rodzaju zabieg doprowadzi do pogorszenia sytuacji finansowej jednostek samorządowych funkcjonujących na obszarze powiatu metropolitalnego.

$\mathrm{Z}$ drugiej jednak strony mamy do czynienia $\mathrm{z}$ sytuacją swoistego rodzaju redystrybucji udziału miast na prawach powiatu we wpływach z podatków PIT i CIT (Poselski..., art. 68, pkt 1). Ustalone przez projektodawcę dochody z tytułu obu podatków na rzecz powiatu metropolitalnego miałby później zostać wtórnie podzielone proporcjonalnie między miasta na prawach powiatu. Projektodawca przewidział również zwolnienie powiatów metropolitalnych na okres 5 lat, ale także miast na prawach powiatu wchodzących w jego zakres w okresie roku następującego po jego utworzeniu, z obowiązku dokonywania wpłat do budżetu państwa z przeznaczeniem na część równoważącą subwencji ogólnej dla powiatów (art. 68, pkt 9). Należałoby w tej sytuacji precyzyjnie wyliczyć, czego projektodawca nie czyni nawet na wybranym przykładzie, jakie skutki finansowe przyniesie zwolnienie powiatów metropolitalnych i miast na prawach powiatu z tzw. janosikowego.

\section{Przepisy przejściowe, dostosowujące i końcowe}

Ten fragment ustawy potwierdza tylko wcześniejsze uwagi krytyczne. Warto zwrócić uwagę na trzy z nich. Po pierwsze w art. 77 (Poselski...) potwierdzono jednoznacznie, że $\mathrm{z}$ dniem utworzenia powiatu metropolitalnego przejmuje on zadania określone w art. 8 wraz ze służącymi do wykonania tych zadań aktywami trwałymi i innymi składnikami majątkowymi należącymi do jednostek samorządu terytorialnego wchodzących w skład powiatu metropolitalnego. Wywłaszczenie gmin stanie się więc faktem. Po drugie, art. 81 pozwala na przejęcie z mocy prawa praw i obowiązków wynikających z członkostwa nowo powstałego powiatu metropolitalnego w związkach oraz stowarzyszeniach, do których należą już wchodzące w jego zakres powiaty lub gminy. Co ważne projektodawca nie określa, co dzieje się z dotychczasowymi członkami tych organizacji, tj. utrzymują czy też tracą oni członkostwo, a może tylko zmienia się cha- 
rakter ich członkostwa? Przepisy w tej materii są daleko nieprecyzyjne. Po trzecie wreszcie, przepisy mówiące o powołaniu pełnomocnika do spraw powiatu metropolitalnego różnią się od analogicznych reguł zawartych chociażby w ustawie o samorządzie gminnym (Poselski..., art. 74-75). Wydaje się, że zasadnym byłoby dostosowanie zapisów do funkcjonujących już wzorców. Dodatkowo, przepisy mówiące o powołaniu zespołu do spraw utworzenia powiatu metropolitalnego są nieprecyzyjne - np. nie dają odpowiedzi na pytanie kto go powołuje (Poselski..., art. 76).

Warto również dodać, że w uzasadnieniu do projektu brakuje wyraźnie wskazanych skutków finansowych proponowanej regulacji, co kłóci się z art. 50 ust. 2 ustawy z dnia 27 sierpnia 2009 roku ofinansach publicznych (Dz. U. 2009, Nr 157, poz. 1240 z późn. zm.), w którym stwierdzono, że ,projekt ustawy skutkującej zmianą poziomu dochodów lub wydatków jednostek samorządu terytorialnego wymaga określenia wysokości skutków tych zmian, wskazania źródeł ich sfinansowania oraz zaopiniowania przez Komisję Wspólną Rządu i Samorządu Terytorialnego".

\section{Podsumowanie}

Podsumowując całość rozważań należy stwierdzić, że poselski projekt ustawy o powiecie metropolitalnym nie przystawał do samorządowej rzeczywistości będącej efektem 25 lat pracy zarówno parlamentarzystów, samorządowców, jak i przedstawicieli świata nauki. Nie ulega jednak wątpliwości, że dobrze się stało, iż ten projekt trafił pod obrady parlamentu, bowiem stał się podstawą do ożywionej dyskusji. W jej efekcie wypracowano de facto nowe rozwiązanie, włącznie ze zmianą nazwy samej ustawy, która w ostatecznej wersji brzmi ustawa z dnia 9 października 2015 roku o zwiazkach metropolitalnych.

Ustawa, która została przyjęta przez Parlament RP i podpisana przez Prezydenta RP ma niewiele wspólnego z pierwotną wersją poselskiej propozycji rozwiązania kwestii metropolitalnej w Polsce po wielu latach burzliwej dyskusji. Trudno jest dziś oceniać efektywność przyjętych rozwiązań, bowiem dopiero praktyka funkcjonowania związków metropolitalnych pokaże, czy decyzja o przyjęciu nowych rozwiązań w takim kształcie była słuszna. Ostateczne rozstrzygnięcie zostanie przeanalizowane przez autora w osobnym opracowaniu. Nie ulega jednak wattpliwości, że po 26 latach funkcjonowania jednostek samorządu terytorialnego w Polsce rozpoczęliśmy nowy rozdział w ich historii. Pewnym jest, że 
należy rozwijać przyjęte już pomysły zakładające wykorzystanie szans, jakie drzemią w polskich obszarach metropolitalnych.

\section{Bibliografia}

Antkowiak P. (2011a), Decentralizacja władzy publicznej w Polsce na przykładzie samorzadu terytorialnego, „Środkowoeuropejskie Studia Polityczne”, nr 2.

Antkowiak P. (2011b), Samorzqd terytorialny na przykladzie miasta Konina, Poznań 2011.

Antkowiak P. (2014), Opinia na temat poselskiego projektu ustawy o powiecie metropolitalnym (druk $n r$ 2107), Warszawa.

Antkowiak P. (2015), Decentralization of public authority as a result of political changes in Poland, „Przegląd Politologiczny”, nr 1.

Biała Księa Obszarów Metropolitalnych (2013), Warszawa.

Dtugookresowa Strategia Rozwoju Kraju Polska 2030. Trzecia fala nowoczesności, 11 stycznia 2013 roku, Warszawa.

Kaczmarek T. (2008), Aglomeracja poznańska jako region badania i działania, w: Powiat poznański. Jakość przestrzeni i jakość życia, red. T. Kaczmarek, A. Mizgajski, Poznań.

Koncepcja Przestrzennego Zagospodarowania Kraju 2030, grudzień 2011, Warszawa.

Krajowa Polityka Miejska, marzec 2014, Warszawa.

Krajowa Strategia Rozwoju Regionalnego 2010-2020: Regiony, miasta, obszary wiejskie, 13 lipca 2010 roku, Warszawa.

Nawrot B. (2011), Obszar metropolitalny jako propozycja zmian w systemie zarzadzania lokalnego w Polsce, w: Wieloaspektowość samorzqdności gminnej w Polsce, red. B. Nawrot, J. Pokładecki, Poznań.

Poselski projekt ustawy o powiecie metropolitalnym (druk nr 2107).

Program Pilotażowy Reformy Administracji Publicznej, Warszawa 1993.

Projekt ustawy o rozwoju miast, centrach rozwoju regionalnego i obszarach metropolitalnych.

Projekt ustawy o polityce miejskiej i współpracy jednostek samorządu terytorialnego w tym zakresie oraz zmianach niektórych innych ustaw.

Projekt ustawy o ustroju obszarów metropolitalnych.

Projekt ustawy o obszarach metropolitalnych.

Słobodzian B. (2011), Gmina - miasto na prawach powiatu - metropolia - w poszukiwaniu efektywnego modelu ustroju miast w Polsce, w: Wieloaspektowość samorzqdności gminnej w Polsce, red. B. Nawrot, J. Pokładecki, Poznań.

Ustawa z dnia 24 listopada 1995 roku o zmianie zakresu dziatania niektórych miast oraz miejskich strefach uslug publicznych, Dz. U. 1997, Nr 36, poz. 224. 
Ustawa z dnia 9 października 2015 roku o zwiazkach metropolitalnych, Dz. U. 2015, poz. 1890.

Wierzba A. (2006), Miasto na prawach powiatu. Zagadnienia ustrojowe, Warszawa. Zielona Księga dotyczqca Obszarów Metropolitalnych, kwiecień 2012, Warszawa.

\section{Parliamentary draft of an act on the metropolitan district - a progress or regression in the reform of local government in Poland?}

\section{Summary}

The development of local government is one of the key factors that contributed to the democratization of the political system in Poland. The process of building local government in Poland is still not finished, and there are new challenges. One of the important issues is the question of increasing role of metropolitan areas and large urban areas. The subject of the article was an analysis of the parliamentary Act on the metropolitan district. The proposed project does not fit the local reality. The good thing was that this project provoked the debate. As a result, it developed a new solution - the Act on metropolitan associations.

Key words: metropolitan area, metropolitan district, local government 